Article

\title{
Assessing the Effect of Rubber (Hevea brasiliensis (Willd. ex A. Juss.) Muell. Arg.) Leaf Chemical Composition on Some Soil Properties of Differently Aged Rubber Tree Plantations
}

\author{
Porntip Puttaso ${ }^{1}$, Weravart Namanusart ${ }^{2}$, Kanjana Thumanu ${ }^{3}$, Bhanudacha Kamolmanit ${ }^{4}$, \\ Alain Brauman 5,6 (iD) and Phrueksa Lawongsa ${ }^{1, *}$ \\ 1 Department of Soil Science and Environment, Faculty of Agriculture, Khon Kaen University, \\ Khon Kaen 40002, Thailand; p.nuchdy@gmail.com \\ 2 Department of Agricultural Technology and Environment, Faculty of Sciences and Liberal Arts, \\ Rajamagala University of Technology, Nakhon Ratchasima 30000, Thailand; weravart2018@gmail.com \\ 3 Synchrotron Light Research Institute (Public Organization), Nakhon Ratchasima 30000, Thailand; \\ kthumanu@gmail.com \\ 4 Department of Agriculture, Faculty of Science and Technology, Nakhon Ratchasima Rajabhat University, \\ Nakhon Ratchasima 30000, Thailand; bhanudacha@yahoo.com \\ 5 Eco\&Sols, University Montpellier, CIRAD, INRA, IRD, Montpellier SupAgro, F-34398 Montperliier, France; \\ alain.brauman@ird.fr \\ 6 LMI LUSES, Land Development Department, Bangkok 10900, Thailand \\ * Correspondence: phrula@kku.ac.th; Tel.: +66-43-364639
}

Received: 4 November 2020; Accepted: 24 November 2020; Published: 27 November 2020

check for updates

\begin{abstract}
Leaf litter plays a major role in carbon and nutrient cycling, as well as in fueling food webs. The chemical composition of a leaf may directly and indirectly influence decomposition rates by influencing rates of biological reactions and by influencing the accumulation of soil organic carbon content, respectively. This study aimed to assess the impact of the chemical composition of rubber (Hevea brasiliensis (Willd. ex A. Juss.) Muell. Arg.) leaves on various soil properties of different ages of rubber (4-5, 11-12, and 22-23 year-old). Synchrotron-based Fourier transform infrared microspectroscopy (Sr-FTIR) was utilized for analyzing the chemical composition of plant leaves. The Sr-FTIR bands illustrated that the epidermis of rubber leaves from 4-5-year-old trees was found to contain a high quantity of polysaccharides while mesophyll from 22-23-year-old trees had a large number of polysaccharides. The change in soil properties in the older rubber plantation could be attributed to its chemical composition. The change in soil properties across all tree ages, i.e., increased litter and organic carbon content, was a relatively strong driver of soil biota evolution. The aliphatic of $\mathrm{C}-\mathrm{H}$ in the leaves showed high correlation with soil organic carbon (SOC) and permanganate-oxidizable C (POXC) from 22-23 year-old trees. This study shows the differences in the organic chemical composition of leaves that are consequential to soil organic carbon.
\end{abstract}

Keywords: rubber tree (Hevea brasiliensis (Willd. ex A. Juss.) Muell. Arg.); synchrotron-based Fourier transform infrared microspectroscopy; leaf chemical composition; soil organic carbon

\section{Introduction}

A rubber tree (Hevea brasiliensis (Willd. ex A. Juss.) Muell. Arg.) or rubber plant is an angiosperm plant belonging to the family Euphorbiaceae Juss.. Among members of the genus Hevea Aubl., rubber trees are considered the most economically important due to the milky latex extracted from the tree, which is the source of natural rubber. The major areas for rubber tree cultivation are 
located in Southeast Asia, especially Indonesia, Malaysia, Thailand, and Vietnam [1]. Rubber trees were first cultivated in Thailand in the 1890s and today rubber is a very important contributor to the Thai economy. The trees are mainly cultivated in southwestern and northeastern Thailand (Department of Agricultural Extension, Ministry of Agriculture and Cooperatives) due to their favorable environmental conditions for planting [2]. As southern Thailand is located in tropical and subtropical areas, their soil contains little organic matter and is less suitable for rubber tree production. Cultivation areas lacking nutrients negatively impact natural latex production. Essential nutrients are derived from leaf fall, which increases organic matter in the soil. In organically managed systems, the mineralization of soil organic matter (SOM) is crucial for meeting crop nutrient demand. The relationship between SOM chemical composition and labile fractions can provide insight into the degree that SOM chemistry can influence lability [3]. The degree of change in SOM composition that can be associated with an increase in SOM is largely unknown and may offer insight into observed labile SOM increases. More studies on the leaf litter of rubber such information about the chemical or litter quality was extremely scarce and only the properties and degradation are studied, the management of degradation is very important to understand the substances present in plant residues. The three main factors controlling the rate of litter decomposition are governed by an interplay of climate, litter quality/soil biota in the physicochemical environment, litter quality, and the composition of the decomposer community. The rate at which nutrients are released from litter is generally governed by the decomposition rate [4].

Fourier transform infrared (FTIR) spectroscopy is an effective tool for the chemical analysis of biological samples [5,6]. This technique offers a rapid, inexpensive, and relatively non-invasive method for obtaining the biochemical fingerprint of a sample. It enables the identification of the main chemical composition and chemical bonds, thus revealing the structural information of biochemical compounds rather than being limited to elemental information [7-9]. Crucially, both organic and inorganic compounds are featured in the FTIR spectrum, allowing for not only identification of the main organic constituents of plant material but also for the characterization of inorganic compounds present in the plant and soil $[10,11]$. Thus, FTIR microscopy is considered an advantageous tool for analyzing interspecies variations in main organic compound proportions. It can also be useful for comparing intraspecies specimen properties, for example specimens growing under different environmental conditions. FTIR spectroscopy is a widely used tool in plant biological studies [5] and has been a credible and efficient tool applied in the fields of natural, medical and agricultural sciences, as in the following studies: (i) plant response to environmental factors [12], impact of heavy metals [13-16], plant identification and classification [17-19], and soil identification [10,20]; (ii) plant pharmaceutical properties [21]; and (iii) crop diseases and pathogens [22,23]. Therefore, the objectives of this study were to use synchrotron-based Fourier transform infrared microspectroscopy (Sr-FTIR) in examining leaf chemical composition of differently aged rubber tree plantations and to characterize its relationship with soil properties.

\section{Materials and Methods}

\subsection{Study Site and Treatment}

The experimental site was located in the Kranuan district, Khon Kaen province, Thailand $\left(16^{\circ} 44^{\prime}-16^{\circ} 75^{\prime} \mathrm{N} ; 103^{\circ} 07-103^{\circ} 08^{\prime}\right.$ E) [24]. A randomized completely block design (RCBD) with three replications was employed due to the area's gentle slope (approximately 1-3\%). Manual weed control was employed at approximately two-month intervals on the youngest rubber plantation. Tree treatments were applied to rubber trees aged: (1) 4-5 years, (2) 11-12 years, and (3) 22-23 years.

\subsection{Plant and Soil Sampling}

To avoid variability in the chemical composition of the plants due to phenology, all plant and soil material was collected in September 2016 during the rainy season. The leaves, along with the petioles, were cut off near the stalk and placed in zip-lock plastic bags. 
Soil samples were taken from randomly selected locations in each plot at $0-15-\mathrm{cm}$ depths. Litter layers were removed before sampling. Soil samples were separated into two categories for soil property and chemical composition analyses and processed as follows: 2-mm soil was used for soil property analysis and soil processed into a fine powder was used for chemical composition analysis. Soil for the latter category was ground using a ball mill (Retsch Mixer MM301, Leeds, UK).

\subsection{Chemical and Biological Analyses and Leaf Chemical Analysis}

Soil organic carbon was measured from air-dried soil via dichromate oxidation [25]. Soil pH was measured with a $\mathrm{pH}$ meter in a soil to water ratio $(1: 2.5)$. Bulk density $\left(\mathrm{g} \mathrm{cm}^{-3}\right)$ was calculated as the ratio of the dry mass of fine soil $(<2 \mathrm{~mm})$ to the cylinder volume. Labile carbon was determined by measuring permanganate-oxidizable C (POXC) according to procedures outlined in Cullman et al. [26]. Soil microbial biomass carbon (MBC) was determined from fresh soil processed immediately after sampling with the chloroform fumigation-extraction technique. The $20 \mathrm{~g}$ soil/sample was fumigated for $48 \mathrm{~h}$ then, soil was extracted with $100 \mathrm{~mL}$ of $1 \mathrm{M} \mathrm{KCL}$. The non-fumigated samples were extracted immediately after sampling and determined microbial biomass nitrogen (MBN) by ninhydrin reaction method [27]. Microbial respiration was measured using the alkaline trap method, which has been applied in previous research to measure field $\mathrm{CO}_{2}$-emission [28]. The soil microbial metabolic quotient $\left(q \mathrm{CO}_{2}\right)$ was expressed in $\mathrm{CO}_{2}-\mathrm{C}$ production per unit $\mathrm{MBC}$ and per unit time.

Leaves were gently washed with distilled water and oven-dried for 3 days at $80^{\circ} \mathrm{C}$. Leaf fibers (hemicellulose, cellulose, and lignin) were identified using the Van Soest method [29].

\subsection{Synchrotron-Based Fourier Transform Infrared (FTIR) Microspectroscopy}

2.4.1. Plant and Soil Sample Preparation for Fourier Transform Infrared (FTIR) Microspectroscopy Analysis

The sample preparation for the treated rubber leaf tissues was prepared by using cryosection technique. The sample was embedded with OCT compound (Tissuse-Trek, Electron Microscopy Science, Hatfield, PA, USA) and snap-frozen with liquid nitrogen then stored at $-80^{\circ} \mathrm{C}$. The samples were cut transversely around 5 microns thick and placed on infrared transparent BaF2 windows $(13 \times 2 \mathrm{~mm})$ for further analysis with infrared microspectroscopy.

Soil samples from each plantation were dried overnight at $32{ }^{\circ} \mathrm{C}$ and were then grounded into fine powder in a ball mill (Retsch Mixer MM301, Leeds, UK).

Spectral acquisition and instrument control were performed using OPUS 7.2 software (Bruker Optics Ltd., Ettlingen, Germany). The spectra were also baseline corrected. No correction was required for water vapor or $\mathrm{CO}_{2}$, as the spectrometer was continuously flushed with dry air.

\subsubsection{Fourier Transform Infrared (FTIR) Microspectroscopy Analysis}

Spectral data of the leaves were collected using an infrared microspectroscopy beamline (BL4.1 Infrared Spectroscopy and Imaging) at Synchrotron Light Research Institute (SLRI). Spectra were acquired with a Vertex 70 FTIR spectrometer (Bruker Options, Ettlingen, Germany) coupled with infrared microscope (Hyperion 2000, Bruker), with an MCT detector cooled with liquid nitrogen over an FTIR measurement range of $4000-900 \mathrm{~cm}^{-1}$. The microscope was connected to a software-controlled microscope stage and placed in a specially designed box purged by dry air. The measurements were performed in transmission mode, using an aperture of $10 \times 10 \mu \mathrm{m}^{2}$ with a spectral resolution of $6 \mathrm{~cm}^{-1}$ and with 64 scans co-added. For soil measurement, the measurements were performed using diamond anvil cell measured in transmission mode using an aperture of $20 \times 20 \mu \mathrm{m}^{2}$ with a spectral resolution of $4 \mathrm{~cm}^{-1}$ and with 64 scans co-added. Spectral acquisition and instrument control were performed using OPUS 7.2 software (Bruker Optics Ltd., Ettlingen, Germany) and analyzed using CytoSpec software. 


\subsubsection{Data Processing and Image Analysis}

The image analysis was analyzed using CYTOSPEC version 2.00.05 infrared image software (CytoSpec Inc., New York, NY, USA). The pre-processed spectra were conducted in order to remove differing sample thicknesses and to observe the small difference between the samples. The color coded imaged was received by doing hierarchical clustering analysis (HCA) of the FTIR data. This analysis can separate the difference of each functional groups based on peak intensity and peak area.

\subsection{Multivariate Data Analysis}

The pre-processed spectra from each group of the sample were conducted by using the Unscrambler software (version 10.5, CAMO software, As, Norway). The spectra were processed by performing the second derivative and vector-normalized values according to the Savitzky-Golay method (3rd polynomial, 13 smoothing points) [23] and the principal component analysis (PCA), which could differentiate the biochemical components of each tissue.

\subsection{Statistical Analyses}

All statistical analyses were conducted using SPSS software version 13.0 (SPSS Institute, Chicago, IL, USA). A difference with $p<0.05$ was considered significant. A one-way ANOVA was computed to detect the differences in SOC, SOM, microbial respiration, and microbial biomass $\mathrm{N}$ and $\mathrm{C}$, among the $0-15 \mathrm{~cm}$ surface soil samples from the differently aged rubber tree plantations. Relationships in terms of leaf features were studied with correlation analysis.

Relationships among the bands and biological properties of the soil were determined using linear correlation analysis. Person's correlation coefficients (R) were calculated for two-directional correlations between absorbance intensities of the bands and biological properties of the soil. $\mathrm{R}$ studio version 3.5.2 was used to evaluate the data.

\section{Results}

\subsection{Soil Properties}

The soil in all treatments had the same physical properties in terms of texture and soil $\mathrm{pH}$, and the bulk density decreased when tree age increased (data not shown). Chemical properties were also affected by age. Indeed, the oldest rubber trees (Hevea brasiliensis (Willd. ex A. Juss.) Muell. Arg.), aged 22-23 years, showed the biggest difference in terms of soil chemical properties in comparison to all other ages (Table 1). The soil organic carbon and permanganate-oxidizable content were higher in rubber plantations aged 22-23 years than in those $4-5$ years, but was not significantly different from those in the second age group (11-12 years). The microbial biomass carbon was significantly lower in plantations aged $4-5$ years. In contrast, the microbial biomass nitrogen and metabolic quotient was significantly higher in the plantations aged 22-23 years. Finally, the soil from under rubber trees aged 22-23 years showed high microbial respiration activity (Table 1). The same applies when soil amendments or food sources such as biochar were added to the soil, which increased the activity of soil microorganisms [30]. Biochemical properties of the rubber tree's leaves are given in Table 2. The cellulose content tended to be higher in trees that were $4-5$ years. Finally, more hemicellulose and lignin were found in rubber trees aged 22-23 years than in the other age groups (Table 2). 
Table 1. Soil properties $(0-15 \mathrm{~cm})$ of differently aged rubber tree plantations.

\begin{tabular}{|c|c|c|c|c|c|c|}
\hline Tree Ages & SOC (\%) & $\begin{array}{l}\text { Microbial Respiration } \\
\quad\left(\mathrm{gCO}_{2} \cdot \mathrm{m}^{-2} \cdot \mathrm{d}^{-1}\right)\end{array}$ & $\begin{array}{c}\mathrm{MBC} \\
\left(\mathrm{mg} \cdot \mathrm{kg}^{-1}\right)\end{array}$ & 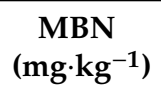 & $q \mathrm{CO}_{2}$ & $\begin{array}{c}\text { POXC } \\
\left(\mathrm{mg}^{\left.-k g^{-1}\right)}\right.\end{array}$ \\
\hline $4-5$ years & $0.26 b$ & $482.5 b$ & $468.0 \mathrm{a}$ & $534.6 a$ & $0.8 b$ & $52.58 \mathrm{c}$ \\
\hline $11-12$ years & $0.30 \mathrm{a}$ & $607.7 \mathrm{ab}$ & $243.6 b$ & $250.6 b$ & $2.5 \mathrm{a}$ & $114.82 \mathrm{~b}$ \\
\hline $22-23$ years & $0.31 \mathrm{a}$ & $685.6 a$ & $260.6 b$ & $453.6 \mathrm{a}$ & $2.2 \mathrm{a}$ & $169.66 a$ \\
\hline$p$-value & $*$ & $* *$ & $*$ & $*$ & $*$ & * \\
\hline
\end{tabular}

SOC: soil organic carbon; MBC: microbial biomass carbon; MBN: microbial biomass nitrogen; POXC: permanganate-oxidizable $\mathrm{C}$. Means marked with different letters within a column differed significantly from each other at a significance level of $p<0.05$ according to LSD's test. ( $\left.{ }^{*} p<0.05\right),\left({ }^{* *} p<0.01\right)$.

Table 2. Biochemical composition of rubber tree leaves.

\begin{tabular}{|c|c|c|c|}
\hline Tree Age & Cellulose $\left(\mathrm{g} \cdot \mathrm{kg}^{-1}\right)$ & Hemicellulose $\left(\mathrm{g} \cdot \mathrm{kg}^{-1}\right)$ & Lignin $\left(g \cdot \mathrm{kg}^{-1}\right)$ \\
\hline $4-5$ years & 29.40 & 10.73 & 24.45 \\
\hline $11-12$ years & 23.69 & 11.21 & 13.36 \\
\hline $22-23$ years & 22.77 & 13.36 & 25.00 \\
\hline
\end{tabular}

\subsection{Synchrotron-Based Fourier Transform Infrared (Sr-FTIR) Microspectroscopy of Soil Organic Carbon}

The bands representing soil organic structure assignment integrated area of differently aged rubber tree plantations (Table 3) while the soil from rubber plantations within the same age range had similar organic wavenumbers. The groups consisted of benzoic acids, $\mathrm{C}-\mathrm{O}$ of aryl ethers, $\mathrm{C}-\mathrm{O}$ of phenolic groups $\left(1253 \mathrm{~cm}^{-1}\right)$, Phenol vas (c-O-, carboxylic acid $v(\mathrm{C}-\mathrm{O})\left(1206 \mathrm{~cm}^{-1}\right), \mathrm{C}-\mathrm{H}$ of aliphatic OH and C-O bands of polyalcoholic and ether, $\mathrm{C}-\mathrm{H}$ of aliphatic $\mathrm{OH}\left(1137 \mathrm{~cm}^{-1}\right)$, and Polysaccharide C-O $\left(1119 \mathrm{~cm}^{-1}, 1105 \mathrm{~cm}^{-1}, 1085 \mathrm{~cm}^{-1}, 1079 \mathrm{~cm}^{-1}, 1067 \mathrm{~cm}^{-1}\right)$. The integral area of each curve representing the average spectra for each chemical composition is described in Table 3. Integration values for benzoic acids, C-O of aryl ethers, and C-O of phenolic groups were found only in rubber tree plantations aged 22-23 years, as were the values for phenol vas (C-O-, carboxylic acid $v(\mathrm{C}-\mathrm{O})$ and polysaccharide (1119, $1105,1085,1079$, and $\left.1067 \mathrm{~cm}^{-1}\right)$. The rubber tree plantations aged $4-5$ years had significantly higher Phenol vas (C-O-, carboxylic acid $v(\mathrm{C}-\mathrm{O}), \mathrm{C}-\mathrm{H}$ of aliphatic $\mathrm{OH}$ and $\mathrm{C}-\mathrm{O}$ bands of polyalcoholic and ether, and $\mathrm{C}-\mathrm{H}$ of aliphatic $\mathrm{OH}\left(1206,1137 \mathrm{~cm}^{-1}\right)$. Soil organic matter supply is mainly derived from plant litter [31].

Table 3. Assigned Fourier transform infrared (FTIR) integrated areas of different ages of rubber tree plantations.

\begin{tabular}{|c|c|c|c|c|}
\hline \multirow[t]{2}{*}{$\begin{array}{l}\text { Wavenumber } \\
\left(\mathrm{cm}^{-1}\right)\end{array}$} & \multirow[t]{2}{*}{ Chemical Composition } & \multicolumn{3}{|c|}{ Tree Age } \\
\hline & & $\begin{array}{c}4-5 \\
\text { Years }\end{array}$ & $\begin{array}{l}11-12 \\
\text { Years }\end{array}$ & $\begin{array}{l}22-23 \\
\text { Years }\end{array}$ \\
\hline 1253 & C-O of phenolic groups [32] & - & - & 3.9 \\
\hline 1206 & Phenol $v_{\text {as }}(\mathrm{C}-\mathrm{O}-$, carboxylic acid $v(\mathrm{C}-\mathrm{O})[33]$ & $12.8 \mathrm{a}$ & $12.0 \mathrm{a}$ & $8.5 b$ \\
\hline 1137 & $\begin{array}{l}\mathrm{C}-\mathrm{H} \text { of aliphatic } \mathrm{OH} \text { and } \mathrm{C}-\mathrm{O} \text { bands of } \\
\text { pholyalcoholic } \\
\text { and ether, } \mathrm{C}-\mathrm{H} \text { of aliphatic } \mathrm{OH}[32,34,35]\end{array}$ & $5.3 a$ & $4.6 \mathrm{a}$ & $2.9 \mathrm{~b}$ \\
\hline 1119-1067 & Polysaccharide C-O $[32,33]$ & $57.5 b$ & $32.0 \mathrm{c}$ & $70.2 \mathrm{a}$ \\
\hline
\end{tabular}

Means marked with different letters within a column differed significantly from each other at a significance level of $p<0.05$ according to LSD's test.

\subsection{Distribution of Carbon Chemical Composition in Plant Leaves}

Rubber tree tissues were comprised of a diverse group of molecules, including proteins, lipids, lignins, pectins, and polysaccharides, and each molecular class had characteristic conformations in line with cell type. Typically, the leaves of higher plants are comprised of epidermis, mesophyll, 
and vascular bundles [32,36]. Previous studies by Thumanu et al. [22] showed that these three tree tissue types can be found in higher plant leaf tissue sections, according to macromolecular chemistry using FTIR microspectroscopy. In this study, we attempted to discern changes in macromolecular biochemistry in the different tissue types of differently aged rubber plant tissues. Figure 1 shows maps of the integrated area of the spectral region equivalent to absorbance intensities over the range of $4000-900 \mathrm{~cm}^{-1}$ (Figure 1a) and a spatial area of $120 \mu \mathrm{m} \times 100 \mu \mathrm{m}$ within a transverse leaf section obtained from a rubber tree (Hevea brasiliensis (Willd. ex A. Juss.) Muell. Arg.) (Figure 1b). As rubber trees are $\mathrm{C}_{4}$ plants, it is difficult to see the vascular bundles. Contrasts within the map are clarified using a color scheme to indicate absorbance intensity: blue is the lowest level of absorbance and pink is the highest (blue $<$ green $<$ yellow $<$ red $<$ pink) (Figure 1b). For the HCA analysis, the spectra were separated based on similarity to and dissimilarity from each biochemical chemical composition. The results showed that the epidermis tissue was coded in blue and red and the mesophyll tissue in green, according to the color index (Figure 2a,b).

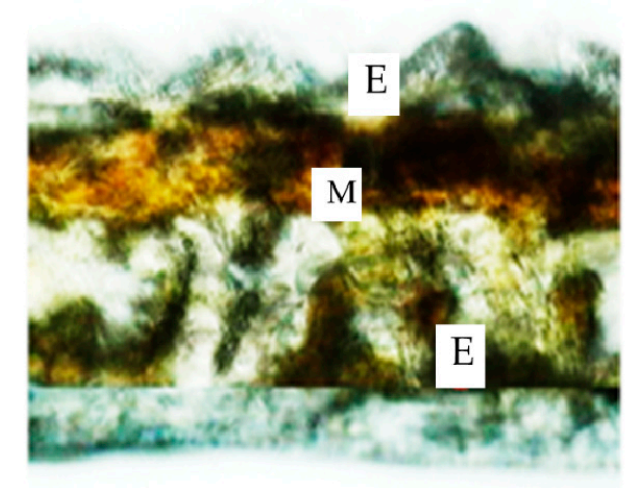

(a)

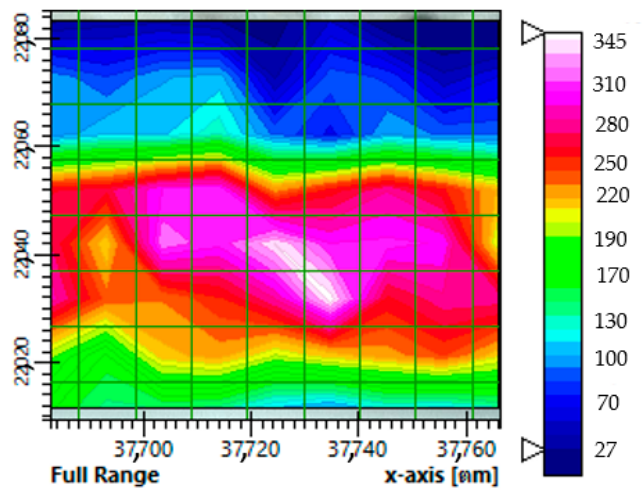

(b)

Figure 1. Chemical composition area maps of part of a transverse leaf section from a rubber tree, which was achieved using Fourier transform infrared (FTIR) microspectroscopy point to point mapping with aperture setting at $15 \times 15 \mu \mathrm{m}$ steps. (a) A micrograph of a rubber tree plantation. (b) Integrated mapping of chemical composition, obtained over the spectral region of $4000-900 \mathrm{~cm}^{-1}$. E, Epidermis; M, Mesophyll.

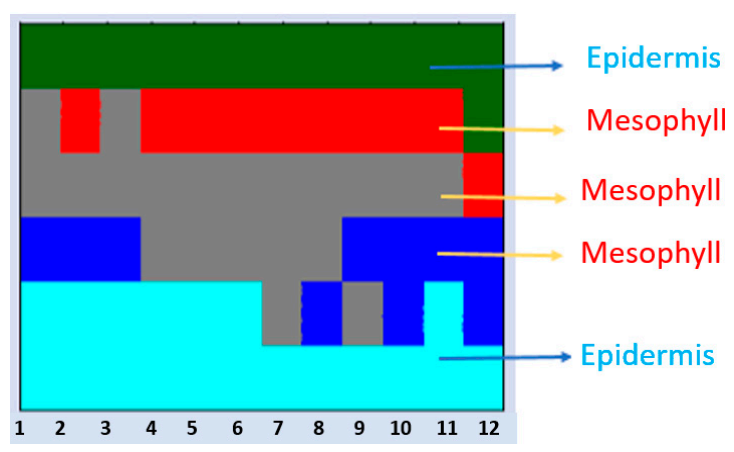

(a)

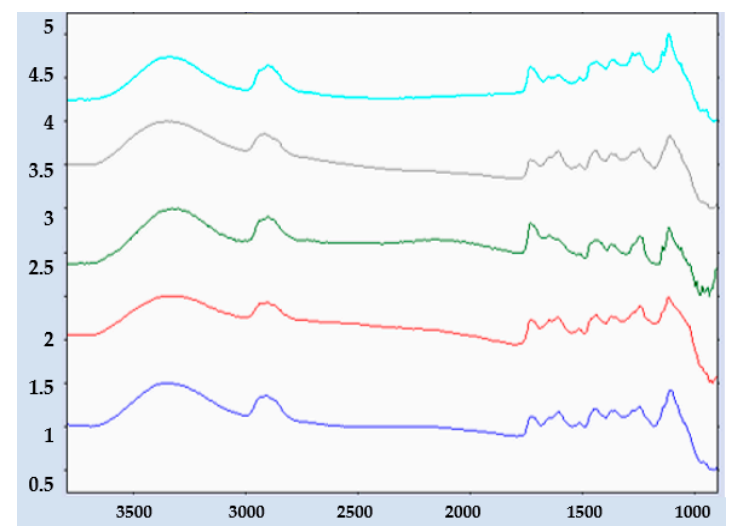

(b)

Figure 2. Fourier transform infrared (FTIR) mapping of rubber tree plantation. Hierarchical cluster analysis (HCA) was performed to determine the separation of spectral groups according to the composition within rubber leaf tissues. (a) The map consists of mesophyll layers (red, gray, blue) and epidermis layers (green and light blue). (b) 2D HCA mapping was produced using 2 clusters in the range of $4000-900 \mathrm{~cm}^{-1}$. 
Multivariate analysis was used to compare the biochemical differences across tissue types and different ages of rubber plantation. Two types of information were extracted from this method: clustering visualization of similar spectra using score plots from datasets and identifying spectra band variables that represent different chemical composition groups present within the samples. Loading plots were used to explain the clustering observed in the score plots [37]. The principal component analysis (PCA) showed a separation by age group, where rubber plantation ages were $4-5$ years, 11-12 years, and 22-23 years (Figure 3). Additionally, the analysis demonstrated that the PC1 and PC2 consistently provided the best clustering of the tree groups. In terms of the epidermis, the PCA score plot was sufficient to visualize the separate groups by their age ranges, at $26 \%$ PC1 and $16 \%$ PC2. The use of multivariate analysis, in particular principal component analysis, has proven useful in the analysis of biospectroscopic data. The high positive loading of the variables in PC1 at 2882, 2836, 1342, 1280,1112 , and $1051 \mathrm{~cm}^{-1}$ corresponded with the negative score plots of the trees aged 11-12 years and 22-23 years. The results shown in old rubber tree high $\mathrm{CH}_{2}$ asymmetrical and symmetrical stretching is related to the metabolism of plants of each age [38]. In contrast, the high negative loading of the variables in PC1 at $1745 \mathrm{~cm}^{-1}$ corresponded with the positive score plot of the treated epidermis group (Figure 3a,b). The PCA score plot derived from the mesophyll tissue was associated with the positive loading plot at $2948,2855,1639,1587,1425,1238,1147$, and $1058 \mathrm{~cm}^{-1}$. The first two PC represented $50 \%$ of the total variance in the data set, with PC1 and PC2 accounting for $35 \%$ and $15 \%$ of the total variance, respectively. The positive loading plot at 2948, 2855, 1639, 1587, 1425, 1238, 1147, and $1058 \mathrm{~cm}^{-1}$ corresponded with the negative score plot of the trees aged 11-12 years (Figure 3c,d). The results of epidermis and mesophyll show the different chemical composition constituents in both areas resulted in different plant life having different food or carbon sources, such as the age when the plant had the amount of chemical composition lignin and hemicellulose, which is difficult to degrade [39].

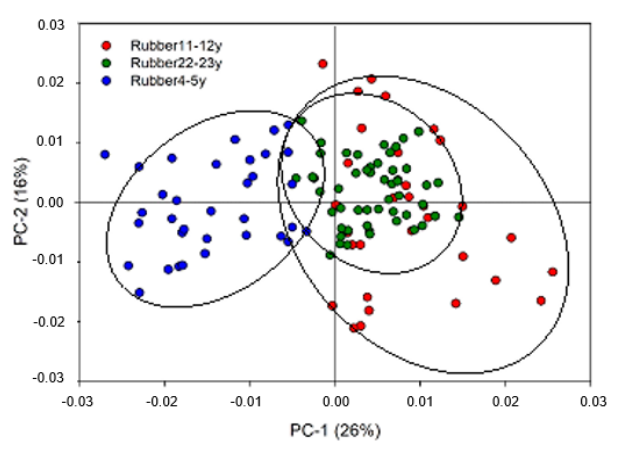

(a)

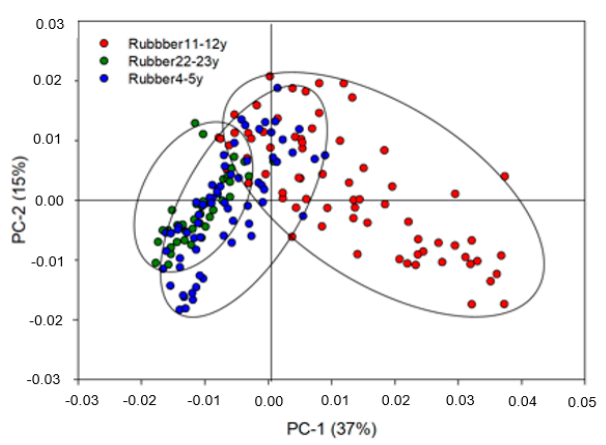

(c)

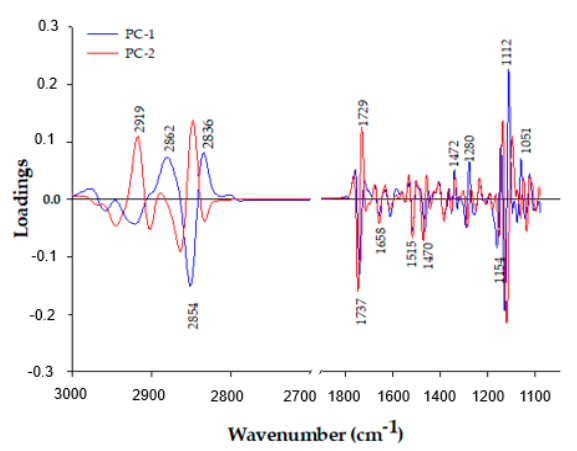

(b)

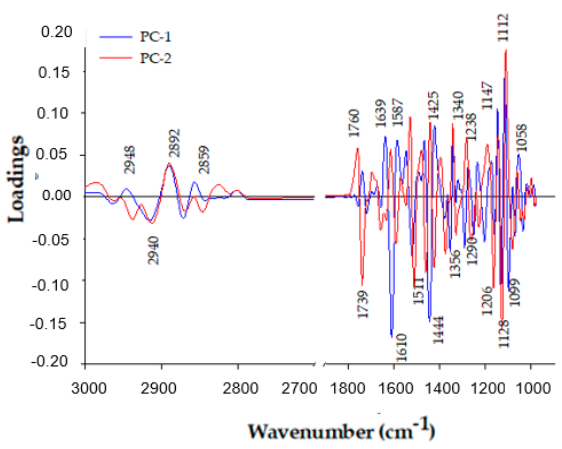

(d)

Figure 3. Principal component analysis (PCA) analyses of rubber tree leaves: $(\mathbf{a}, \mathbf{b})$ Score and loading plots derived from the PCA analyses of epidermis groups; $(\mathbf{c}, \mathbf{d})$ score and loading plots derived from the PCA analyses of the mesophyll. 
In order to compare spectral changes occurring in the protein, lipid, and polysaccharides, the average spectra from the epidermis and mesophyll regions of different ages of rubber tree (4-5 years, 11-12 years, and 22-23 years) were calculated and are presented in Figure 4a,b. Significantly, the band in the region of $2990-2800 \mathrm{~cm}^{-1}$ to $1737 \mathrm{~cm}^{-1}$, assigned to $\mathrm{CH}$-stretching and $\mathrm{C}=\mathrm{O}$ ester, was higher in absorbance in terms of the average spectrum of the 11-12 years, and 22-23 year trees. A comparison of spectra extracted from the mesophyll tissue is shown in Figure $3 b$. In the epidermis and mesophyll, Amide I protein, $\mathrm{C}=\mathrm{C}$, aromatic lignin, and $\mathrm{CH}$ bending peaks, centered at 1656, 1465,1515 , and $1467 \mathrm{~cm}^{-1}$, were intense during the 11-12 years. Absorbance in the polysaccharide region (1200-900 $\mathrm{cm}^{-1}$ ) was higher in the epidermis of the 4-5 years treatment compared to the 22-23 years treatment, for which absorbance was higher in the mesophyll. Differences in structural polysaccharides in rubber leaf were largely a matter of variation in levels or relative proportions of two main classes of these compounds-i.e., hemicellulose (amorphous matrix) and cellulose (fiber)—rather than one of the differences in polysaccharide within either class. Considerable variations in levels of these structural polysaccharides can occur in the growing plant [40]. For this reason, the amount of polysaccharide differed in the epidermis and mesophyll. Therefore, polysaccharide content was directly proportional to the quantity of cellulose and hemicellulose, as shown in Figure 5. The fingerprint region contained several polymers of different types, such as protein, aromatics, and polysaccharides, with particular molecular conformation, as shown in Table 2. Chemical composition differed in the epidermis and mesophyll between the $4-5$ years, and $22-23$ year trees, showing a significant spectra shift: $1280-1274 \mathrm{~cm}^{-1}$ versus less than $1000 \mathrm{~cm}^{-1}$. This was likely associated with a change in the construction and formation according to the age of the plant and cell well.

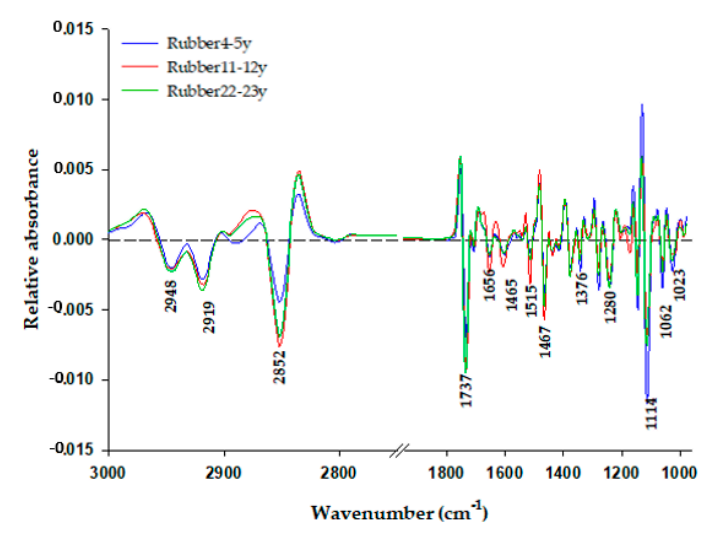

(a)

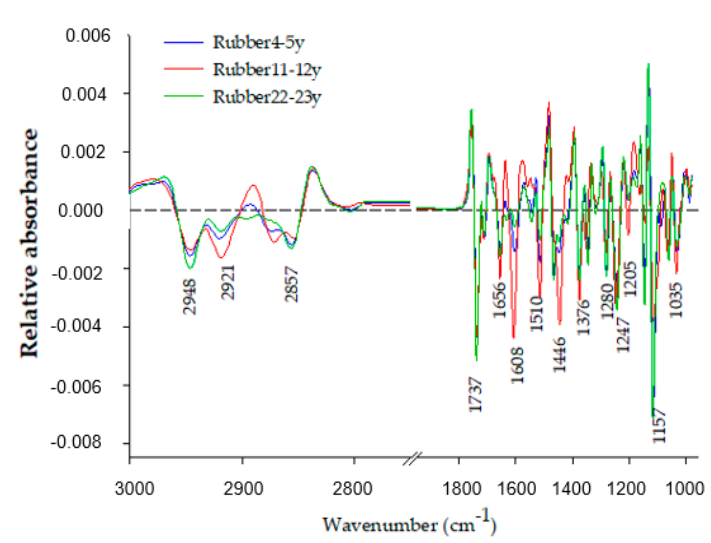

(b)

Figure 4. An overlay of second-derivative average spectra from differently aged rubber tree plantations: (a) Epidermis and (b) mesophyll. The average second derivative spectra were calculated after 13 points of smoothing and normalization, with extended multiplicative signal correlation over the spectral ranges of 3000-2800 and $1800-900 \mathrm{~cm}^{-1}$.

In order to visualize differences in the spectra resulting from aging of the rubber tree plantation, the mean integrated areas were calculated. Differences in spectra between the epidermis and mesophyll groups were observed (Figure $4 a, b)$. Spectral changes were observed for $\mathrm{C}=\mathrm{O}$ stretching (1278-1241 $\mathrm{cm}^{-1}$ ) and CO CC of polysaccharide 1145, 1114, 1060, and $1031 \mathrm{~cm}^{-1}$ (Table 4). In order to contrast the three groups, the mean integrated area of original spectra for each wavenumber was calculated (Figure 5a,b). In the epidermis, $\mathrm{C}=\mathrm{O}$ stretching, hemicellulose $\left(1278-1241 \mathrm{~cm}^{-1}\right.$ ) and CO CC polysaccharides at $1145,1114,1060$, and $1031 \mathrm{~cm}^{-1}$ were higher in the $4-5$ years plants. In contrast, in the mesophyll, $\mathrm{C}=\mathrm{O}$ stretching, hemicellulose $\left(1278-1241 \mathrm{~cm}^{-1}\right)$, and CO CC polysaccharides at 1145 , 1114,1060 , and $1031 \mathrm{~cm}^{-1}$ were higher in the $22-23$ years plants. These biochemical changes were associated with hemicellulose and polysaccharides, as both have been shown to be highly cumulative 
in both life stages of the plant, i.e., the initial growth and very old age. In addition, the Figure 5 shows that the mean integrated area of rubber (11-12 years) has high protein $\left(1654 \mathrm{~cm}^{-1}\right)$. This indicates that the protein production of leaf is not dependent only on ages but that there are still other reasons, such as intensive management of farmers, for fertilization. This corresponded to previous research of Puttaso [24], who utilized urea as a substrate in the soils of different ages of rubber and found that 11-12 years had the highest microbial activity compared with other rubber ages. Therefore, leaf rubber at 11-12 years directly affected microbial activity.

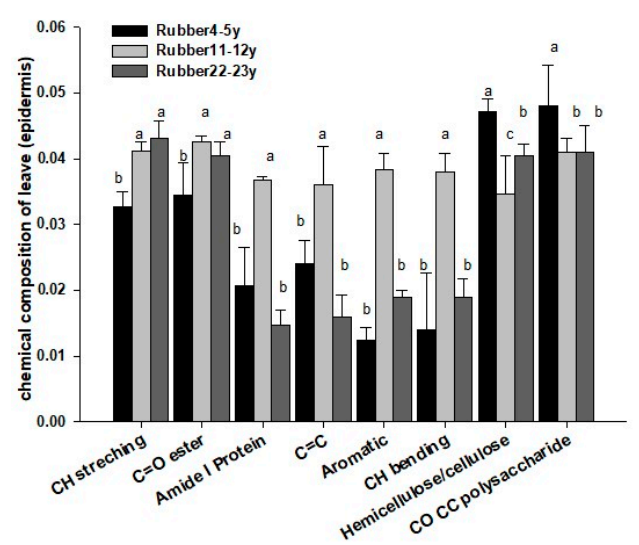

(a)

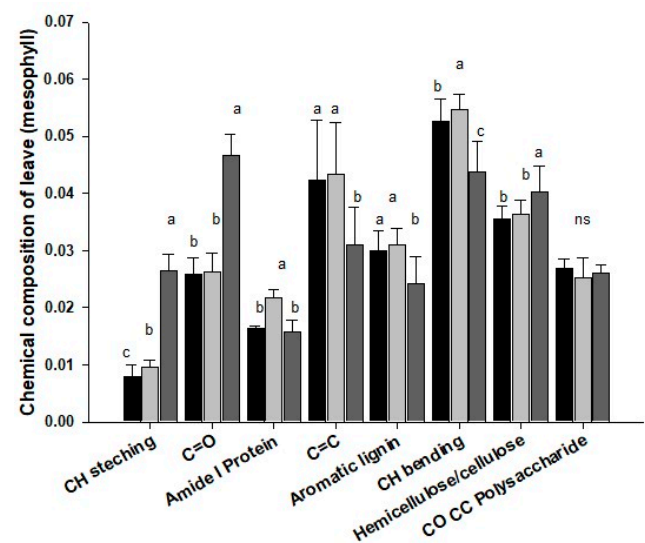

(b)

Figure 5. The integral area of average spectra in the (a) epidermis and (b) mesophyll of rubber tree plants from differently aged plantations. Data followed by the different letters $(a, b$, and $c)$ are significantly different at $p<0.05$. ns: not significantly different.

Table 4. Infrared (IR) band assignments of plant tissues.

\begin{tabular}{ccc}
\hline Wavenumber $\left(\mathbf{c m}^{-\mathbf{1}}\right)$ & Chemical Composition & Reference \\
\hline $2946-2850$ & $\mathrm{CH}_{2}$ asymmetrical and symmetrical stretching & {$[24]$} \\
\hline 1737 & $\mathrm{C}=\mathrm{O}$ ester from lignin and hemicellulose/pectin & {$[3,24,41-43]$} \\
\hline 1654 & Amide I & {$[24,41,44]$} \\
\hline 1515 & $\mathrm{C}=\mathrm{C}^{2}$ aromatic ring from lignin & {$[45]$} \\
\hline 1444,1370 & $\begin{array}{c}\text { Symmetric } \mathrm{CH}_{2} \text { and } \mathrm{CH}_{3} \text { bending from lipids, } \\
\text { protein, and lignin }\end{array}$ & {$[3]$} \\
\hline 1278,1241 & hemicellulose & {$[46]$} \\
\hline $1145,1114,1060,1031$ & $\begin{array}{c}\text { Mainly CO CC of polysaccharides, which are very } \\
\text { complex and depend upon contributions from } \\
\text { polysaccharides, cellulose, hemicellulose, and pectin }\end{array}$ & {$[40,47]$} \\
\hline
\end{tabular}

\section{Discussion}

\subsection{Relationships of Synchrotron-Based Fourier Transform Infrared (Sr-FTIR) Bands with Bio-Chemical Properties of Soil}

To assess the response of leaf chemical composition to the growth stage of rubber trees, we correlated spectral absorbance of each wavenumber range with soil organic carbon. The correlation coefficients were statistically significant for 22-23 year trees at 3000-2776, 1105, and $1155 \mathrm{~cm}^{-1}$ (Figure 3a,b) in the spectral region associated with $\mathrm{C}-\mathrm{H}$ stretching of aliphatic compounds and C-O-C glycosidic ether, mainly hemicellulose and C-C ring cellulose (Table 3). Spectra of 11-12 year trees exhibited significant differences according to the age of rubber and the absorbance of the spectra region at 1700-1600 and 1500-1300 $\mathrm{cm}^{-1}$ (Figure 3a,b); these regions were associated with structural amide I and C-O stretching 
from hemicellulose and lignin (Table 3 ). The $4-5$ year trees showed a significant spectral response to age (Figure 3a,b) in the absorbance of spectra region at 1510 and $1300-1200 \mathrm{~cm}^{-1}$, associated with structural $\mathrm{C}=\mathrm{C}$ aromatic from lignin, $\mathrm{C}-\mathrm{O}$ stretching from hemicellulose, lignin, and polysaccharides. In contrast, the chemical composition of soil indicated high polysaccharides in the 22-23 year plant samples.

In this study, the Sr-FTIR microspectroscopy analysis changed the biochemical composition of rubber plant leaf tissue and its relation changed in organic carbon to soil. This technique enabled us to investigate leaf sections at a high spatial resolution and revealed macromolecular differences between rubber leaves. This technique, combined with PCA, can be used to resolve questions related to chemical structural information of the various tissue types in the plant leaf cell and soil [22,48]. Importantly, PCA enables the exploration of spectral changes in both the leaf cell and soil at different ages. Our results suggest spectral differences in both leaf cell and soil. The addition bands represented organic chemical composition group, including aliphatic $\mathrm{C}-\mathrm{H}, \mathrm{C}=\mathrm{O}$ ester chemical composition, with increased SOC in 22-23 year rubber tree samples (Table 5 ). The greater differentiation by age in wavenumber range of aliphatic $\mathrm{C}-\mathrm{H}$ relative to other chemical composition reflects the SOC, since aliphatic bands were most associated with SOC and POXC compared with other bands, suggesting that these aliphatic $\mathrm{C}-\mathrm{H}$ bands mark the presence of labile carbon [49].

Table 5. Correlation between biochemical qualities and certain soil properties $\left({ }^{*} p<0.05,{ }^{* *} p<0.01\right)$.

\begin{tabular}{cccc}
\hline Biochemical Quality & SOC & POXC & Bulk Density \\
\hline Cellulose & $-0.74^{* *}$ & $-0.78^{* *}$ & $0.69^{*}$ \\
Hemicellulose & & $0.79^{*}$ & $-0.77^{*}$ \\
Lignin & & $0.69^{* *}$ \\
\hline SOC: soil organic carbon; POXC: permanganate-oxidizable C.
\end{tabular}

The higher integral areas of $\mathrm{C}-\mathrm{H}$ bending could be related to the methoxy phenolic substitution of aromatic units, such as the syringyl and guaiacyl in lignin. These changes could indicate lignin formation. Lignin is a cell wall component that is covalently linked to hemicellulose, cellulose, and cross-linked to various plant polysaccharides in the chemical composition of soil with high polysaccharide in 22-23 year trees. Aliphatic $\mathrm{C}-\mathrm{H}$ functionalities include methylene $\left(-\mathrm{CH}_{2}\right)$ and methyl $\left(-\mathrm{CH}_{3}\right)$ groups that occur within chemical composition such as amide $\mathrm{N}-\mathrm{H}$ and aromatic $\mathrm{C}=\mathrm{C}$ in organic macromolecules (e.g., polypeptides), and they are present in compounds considered labile (e.g., amino sugars) and recalcitrant (e.g., lignin). This has been proposed to result from higher inputs of aliphatic-rich OM (e.g., plant residues from cover crops) and is associated with increases in labile and total soil carbon [50]. In this study, the new bands representing organic chemical composition, including C-O stretching of polysaccharides found in the soil sample but not in leaf cells, were classified into phenolic and polysaccharide groups, whereas the leaf residue did not significantly affect the number of soil organic carbon chemical composition. On the other hand, organic carbon input from leaf litter did not directly contribute to the formation of soil organic carbon chemical fractions, but the soil microbial community could be a main factor influencing the chemical composition of soil organic carbon [51]. In addition, the chemical composition of soil organic carbon and the leaf sample was of $\mathrm{C}-\mathrm{H}$. In this study, positive associations of aliphatic C-H bands with soil organic carbon as well as labile organic carbon fractions, in particular MBC, POXC, and organic carbon in soil, implicate changes in aliphatic C-H increasing labile carbon (Table 6), indicating that soil microbial residues could contribute to these labile substrates decomposing. This may explain previous findings of proportionally greater increases in labile organic matter under management that increases organic matter content [51]. Additionally, chemical composition groups of SOM could be constrained by similar stoichiometric limitations in living OM (e.g., membrane lipids, proteins) [52]. POXC and MBC are considered labile fractions and are strongly associated [25,53], yet in this study they showed different associations with chemical composition, suggesting that differences in chemical composition chemistry may underlie similar soil organic carbon, especially the labile carbon fraction. 
Table 6. Correlations between absorbance intensity of epidermis and mesophyll of rubber tissue reflectance, with synchrotron-based Fourier transform infrared (Sr-FTIR) bands representing organic chemical composition, and certain soil properties $\left({ }^{*} p<0.05,{ }^{* *} p<0.001\right)$.

\begin{tabular}{|c|c|c|c|c|c|c|c|c|}
\hline \multirow[t]{2}{*}{$\begin{array}{l}\text { Wavenumber } \\
\quad\left(\mathrm{cm}^{-1}\right)\end{array}$} & \multirow[t]{2}{*}{ Chemical Composition } & \multicolumn{4}{|c|}{ Soil Properties } & \multicolumn{3}{|c|}{ Biochemical Quality } \\
\hline & & SOC & POXC & MBC & Bulk Density & Cellulose & Hemicellulose & Lignin \\
\hline \multicolumn{9}{|l|}{ Epidermis } \\
\hline $2946-2850$ & $\mathrm{CH}_{2}$ asymmetrical and symmetrical stretching & $0.68 *$ & 0.84 * & & $0.8^{*}$ & & $-0.70 *$ & \\
\hline 1737 & $\mathrm{C}=\mathrm{O}$ ester from lignin and hemicellulose/pectin & & & $-0.80 *$ & & & & \\
\hline 1444,1370 & $\begin{array}{l}\text { Symmetric } \mathrm{CH}_{2} \text { and } \mathrm{CH}_{3} \text { bending from lipids, } \\
\text { protein, and lignin }\end{array}$ & 0.69 * & 0.70 * & & & & & \\
\hline \multicolumn{9}{|l|}{ Mesophyll } \\
\hline $2946-2850$ & $\mathrm{CH}_{2}$ asymmetrical and symmetrical stretching & $0.68 *$ & 0.84 * & & $0.8^{*}$ & & & \\
\hline 1654 & Amide I & & & & & & & $-0.93^{* *}$ \\
\hline 1515 & $\mathrm{C}=\mathrm{C}$ aromatic ring from lignin & $-0.69 *$ & $-0.70 *$ & & & & $0.97 * *$ & \\
\hline 1444,1370 & $\begin{array}{l}\text { Symmetric } \mathrm{CH}_{2} \text { and } \mathrm{CH}_{3} \text { bending from lipids, } \\
\text { protein, and lignin }\end{array}$ & & & & & & & $0.70 *$ \\
\hline $\begin{array}{l}1145,1114,1060, \\
1031\end{array}$ & $\begin{array}{l}\text { Mainly C-O-C of polysaccharides, which very } \\
\text { complex and depend upon contributions from } \\
\text { polysaccharides, cellulose, hemicellulose, } \\
\text { and pectin }\end{array}$ & & & & & $0.94^{* *}$ & & -0.90 * \\
\hline
\end{tabular}


4.2. Relationships of Synchrotron-Based Fourier Transform Infrared (Sr-FTIR) Peak Areas with the Biochemical Composition of the Rubber Leaf and Certain Soil Properties

Certain Sr-FTIR peak areas derived from the soils and rubber leaves were correlated with the initial biochemical quality of organic residues (i.e., cellulose, hemicellulose, and lignin) (Table 5). In the epidermis, hemicellulose was negatively correlated with aliphatic $\mathrm{CH}$ stretching $\left(2946-2850 \mathrm{~cm}^{-1}\right)$ $(p<0.05)$. In the mesophyll (Table 5), amid I $\left(1654 \mathrm{~cm}^{-1}\right)$ and polysaccharides $(1145,1114,1060$, $\left.1031 \mathrm{~cm}^{-1}\right)$ were negatively correlated with lignin. The lignin of $C=C$ aromatic ring $\left(1444,1310 \mathrm{~cm}^{-1}\right)$ were negatively correlated with lignin. The lignin of $C=C$ aromatic ring $\left(1444,1310 \mathrm{~cm}^{-1}\right)$ was positively correlated with lignin and hemicellulose as well as with C-O-C of polysaccharides $(1145,1114,1060$, $1031 \mathrm{~cm}^{-1}$ ). Additionally, the biochemical quality showed a correlation with certain soil properties. SOC and POXC had a negative correlation with cellulose and hemicellulose and a positive correlation with POXC (Table 6). This findings were in line with $[3,38,39,54]$, all of whom reported on the close interactions between lignin and cellulose through the formation of covalent bonds as a regulator of litter decay. Additionally, their use of Sr-FTIR as a technique to analyze plant chemical composition resulted in the same correlations.

\section{Conclusions}

This study showed that synchrotron-based Fourier transform infrared (Sr-FTIR) is a powerful tool that can examine changes in chemical composition within plant tissue through rapid and in-depth analysis. Moreover, this technique allowed us to see the chemical structure of different types of plant tissues. This study demonstrated that there is a significant difference in organic functional group composition of leaves detectable by Sr-FTIR among different ages of rubber. These changes were strongly related to SOC and specific labile carbon fractions (POXC and MBC). An increase in the functional group representing aliphatic $\mathrm{C}-\mathrm{H}$ had a strong and positive association with SOC. Soil organic matter transformations influencing specific labile pools may, therefore, involve changes in relative aliphatic C-H abundance. This information will help us to understand the relationship between the chemical composition of plant tissue and soil health.

Author Contributions: Conceptualization, P.P., A.B., and P.L.; methodology, P.P., W.N., K.T., A.B., B.K., and P.L.; formal analysis, P.P., W.N., K.T., A.B., and P.L.; resources, P.P., A.B., and P.L.; software, W.N., K.T., A.B., and P.L.; data curation, P.P., W.N., K.T., A.B., B.K., and P.L.; writing-original draft preparation, P.P., W.N., K.T., A.B., B.K., and P.L.; writing-review and editing, P.P., W.N., K.T., A.B., B.K., and P.L.; supervision, A.B. and P.L.; validation, P.P. and P.L.; project administration, P.P. and P.L.; funding acquisition, A.B. and P.L. All authors have read and agreed to the published version of the manuscript.

Funding: This research was funded by Jeunes équipes associées à l'IRD program (JEAI), the Research Institute for Development (France), Knowledge Development for Rubber Trees in the Northeast (KDRN-KKU) research group, and the Graduate School, Khon Kaen University.

Acknowledgments: This work was supported by a grant from Jeunes équipes associées à l'IRD program (JEAI) and the Knowledge Development for Rubber Tree in the Northeast (KDRN-KKU) research group, Khon Kaen University. Special thanks to the Land Development Department, LMI LUSES and IRD, for their technical support. We are also grateful to the Graduate School, KKU that provided a Thesis Support Scholarship to the first author.

Conflicts of Interest: The authors declare no conflict of interest.

\section{References}

1. Li, Z.; Fox, J.M. Mapping rubber tree growth in mainland Southeast Asia using time-series MODIS $250 \mathrm{~m}$ NDVI and statistical data. Appl. Geogr. 2012, 32, 420-432. [CrossRef]

2. Thaochan, N.; Pornsuriya, C.; Chairin, T.; Sunpapao, A. Role of systemic fungicide in antifungal activity and induced defense responses in rubber tree (Hevea brasiliensis) against leaf fall disease caused by Neopestalotiopsis cubana. Physiol. Mol. Plant. Pathol. 2020, 111, 101511. [CrossRef]

3. Calderon, F.J.; Mikha, M.M.; Vigil, M.F.; Nielsen, D.C.; Benjamin, J.G.; Reeves, J.B. Diffuse-reflectance mid-infrared spectral properties of soil under alternative crop rotations in a semi-arid climate. Commun. Soil. Sci. Plant Anal. 2011, 42, 2143-2159. [CrossRef] 
4. Stohlgren, T.J. Litter dynamic in two Sierran mixed conifer forest. I. Litterfall and decomposition rates. Can. J. For. Res. 1988, 18, 1127-1135. [CrossRef]

5. Baker, M.J.; Trevisan, J.; Bassan, P.; Bhargava, R.; Butler, H.J.; Dorling, K.M.; Fielden, P.R.; Fogarty, S.W.; Fullwood, N.J.; Heys, K.A.; et al. Using Fourier transform IR spectroscopy to analyze biological materials. Nat. Protoc. 2014, 9, 1771-1791. [CrossRef]

6. Bouyanfif, A.; Liyanage, S.; Hequet, E.; Moustaid-Moussa, N.; Abidi, N. Review of FTIR microspectroscopy applications to investigate biochemical changes in C. elegans. Vib. Spectrosc. 2018, 96, 74-82. [CrossRef]

7. Ribeiro da Luz, B. Attenuated total reflectance spectroscopy of plant leaves: A tool for ecological and botanical studies. New Phytol. 2006, 172, 305-318. [CrossRef]

8. Schulz, H.; Baranska, M. Identification and quantification of valuable plant substances by IR and Raman spectroscopy. Vib. Spectrosc. 2007, 43, 13-25. [CrossRef]

9. Talari, A.C.S.; Martinez, M.A.G.; Movasaghi, Z.; Rehman, S.; Rehman, I.U. Advances in Fourier transform infrared (FTIR) spectroscopy of biological tissues. Appl. Spectrosc. Rev. 2017, 52, 456-506. [CrossRef]

10. Smith, B.C. Fundamentals of Fourier Transform Infrared Spectroscopy, 2nd ed.; CRC Press: Boca Raton, FL, USA, 2011; ISBN 978-1-4200-6929-7.

11. Lawongsa, P.; Somboon, S.; Kamolmanit, B.; Namanusart, W.; Thumanu, K. The appearance of soil organic carbon compositions for short-term applications of biochemical contrasting organic residue using synchrotron-based fouier transform infrared (FTIR) microspectroscopy. Biosci. Res. 2020, 17, 257-266.

12. Euring, D.; Löfke, C.; Teichmann, T.; Polle, A. Nitrogen fertilization has differential effects on $\mathrm{N}$ allocation and lignin in two Populus species with contrasting ecology. Trees 2012, 26, 1933-1942. [CrossRef]

13. Usman, K.; Al-Ghouti, M.A.; Abu-Dieyeh, M.H. The assessment of cadmium, chromium, copper, and nickel tolerance and bioaccumulation by shrub plant Tetraena qataranse. Sci. Rep. 2019, 9, 5658. [CrossRef] [PubMed]

14. McNear, D.H.; Chaney, R.L.; Sparks, D.L. The hyperaccumulator Alyssum murale uses complexation with nitrogen and oxygen donor ligands for Ni transport and storage. Phytochemistry 2010, 71, 188-200. [CrossRef] [PubMed]

15. Xue, S.G.; Zhu, F.; Ye, C.; Wang, J.; Wu, X.E. Physiological response of Mirabilis jalapa Linn to lead stress by FTIR spectroscopy. Acta Ecol. Sin. 2011, 31, 6143-6148. [CrossRef]

16. Wei, Z.L.; Dong, L.; Tian, Z.H. Fourier transform infrared spectrometry study on early stage of cadmium stress in clover leaves. Pak. J. Bot. 2009, 41, 1743-1750.

17. Traoré, M.; Kaal, J.; Cortizas, A.M. Differentiation between pine woods according to species and growing location using FTIR-ATR. Wood Sci. Technol. 2018, 52, 487-504. [CrossRef]

18. Rana, R.; Herz, K.; Bruelheide, H.; Dietz, S.; Haider, S.; Jandt, U.; Pena, R. Leaf attenuated total reflection Fourier transform infrared (ATR-FTIR) biochemical profile of grassland plant species related to land-use intensity. Ecol. Indic. 2018, 84, 803-810. [CrossRef]

19. Yu, P. Molecular chemistry imaging to reveal structural features of various plant feed tissues. J. Struct. Biol. 2005, 150, 81-89. [CrossRef]

20. Somboon, S.; Kamolmanit, B.; Namanusart, W.; Thammanu, K.; Lawongsa, P. Changes in soil organic carbon composite resulting from long-term application of biochemical contrasting organic residues monitoring by synchrotron-based FTIR microspectroscopy. Biosci. Res. 2018, 15, 2542-2550.

21. Ashokkumar, R.; Ramaswamy, M. Phytochemical screening by FTIR spectroscopic analysis of leaf extracts of selected Indian medicinal plants. Int. J. Curr. Microbiol. Appl. Sci. 2014, 3, 395-406.

22. Sankaran, S.; Maja, J.M.; Buchanon, S.; Ehsani, R. Huanglongbing (citrus greening) detection using visible, near infrared and thermal imaging techniques. Sensors 2013, 13, 2117-2130. [CrossRef] [PubMed]

23. Thumanu, K.; Mathukorn, S.; Phansak, P.; Nontapot, K.; Buensanteai, N. Use of infrared microspectroscopy to determine leaf biochemical composition of cassava in response to Bacillus subtilis CaSUT007. J. Plant Interact. 2015, 10, 270-279. [CrossRef]

24. Puttaso, P.; Lawongsa, P. Impact of Chronosequence of rubber tree plantation on soil microbial activity. J. Pure Appl. Microbiol. 2018, 12, 1085-1091. [CrossRef]

25. Allison, L.E. Organic carbon. In Methods of Soil Analysis, Part 2, Chemical and Microbiological Properties; Black, C.A., Ed.; American Society of Agronomy: Madison, WI, USA, 1965; pp. 1367-1378; ISBN 978-0-8911-8374-7. [CrossRef] 
26. Culman, S.W.; Snapp, S.S.; Freeman, M.A.; Schipanski, M.E.; Beniston, J.; Lal, R.; Drinkwater, L.E.; Franzluebbers, A.J.; Glover, J.D.; Grandy, A.T.; et al. Permanganate oxidizable carbon reflects a processed soil fraction that is sensitive to management. Soil Sci. Soc. Am. J. 2012, 76, 494-504. [CrossRef]

27. Amato, M.; Ladd, J.N. Assay for microbial biomass based on ninhydrin reactive nitrogen in extracts of fumigated soil. Soil. Biol. Biochem. 1988, 20, 107-114. [CrossRef]

28. Anderson, J.P.E. Soil Respiration. In Methods of Soil Analysis, Part 2, 2nd ed.; Page, A.L., Miller, R.H., Keeney, D.R., Eds.; American Society of Agronomy: Madison, WI, USA, 1982; pp. 837-871; ISBN 978-0-8911-8072-2. [CrossRef]

29. Kocsis, T.; Kotroczó, Z.; Kardos, L.; Biró, B. Optimization of increasing biochar doses with soil-plant-microbial functioning and nutrient uptake of maize. Environ. Technol. Innov. 2020, 101191. [CrossRef]

30. Goering, H.K.; Van Soest, P.J. Forage Fiber Analyses (Apparatus, Reagents, Procedures, and Some Applications); United State, Agricultural Research Service: Washington, DC, USA, 1970; pp. 387-598.

31. Tatzber, M.; Stemmer, M.; Spiegel, H.; Katzlberger, C.; Haberhauer, G.; Mentler, A.; Gerzabek, M.H. FTIR-spectroscopic characterization of humic acids and humin fractions obtained by advanced $\mathrm{NaOH}$, $\mathrm{Na}_{4} \mathrm{P}_{2} \mathrm{O}_{7}$, and $\mathrm{Na}_{2} \mathrm{CO}_{3}$ extraction procedures. J. Plant Nutr. Soil Sci. 2007, 170, 522-529. [CrossRef]

32. Parikh, S.J.; Goyne, K.W.; Margenot, A.J.; Mukome, F.N.; Calderón, F.J. Soil chemical insights provided through vibrational spectroscopy. In Advances in Agronomy; Academic Press: New York, NY, USA, 2014; Volume 126, pp. 1-148.

33. Demyan, M.S.; Rasche, F.; Schütt, M.; Smirnova, N.; Schulz, E.; Cadisch, G. Combining a coupled FTIR-EGA system and in situ DRIFTS for studying soil organic matter in arable soils. Biogeosciences 2013, 10, 2897-2913. [CrossRef]

34. Egli, M.; Mavris, C.; Mirabella, A.; Giaccai, D. Soil organic matter formation along a chronosequence in the Morteratsch proglacial area (Upper Engadine, Switzerland). Catena 2010, 82, 61-69. [CrossRef]

35. Spaccini, R.; Piccolo, A. Molecular characterization of compost at increasing stag of maturity. 1. Chemical fractionation and infrared spectroscopy. J. Agric. Food Chem. 2007, 55, 2293-2302. [CrossRef]

36. Yu, P. Application of advanced synchrotron-based Fourier transform infrared microspectroscopy (SR-FTIR) to animal nutrition and feed science: A novel approach. J. Nutr. 2004, 92, 869-885. [CrossRef] [PubMed]

37. Skotti, E.; Kountouri, S.; Bouchagier, P.; Tsitsiannis, D.I.; Polissiou, M.; Tarantilis, P.A. FTIR spectroscopic evalution of change in the cellular biochemical composition of the phytopathogenic fugus Alternaria alternate induced by extracts of some Greek medicinal and aromatic plants. Spectrochim. Acta A Mol. Biomol. Spectrosc. 2014, 127, 463-472. [CrossRef] [PubMed]

38. Kotroczó, Z.; Juhos, K.; Biró, B.; Kocsis, T.; Pabar, S.A.; Fekete, I.; Varga, C. Effect of Detritus Manipulation on Different Organic Matter Decompositions in Temperate Deciduous Forest Soils. Forests 2020, 11, 675. [CrossRef]

39. Bowden, R.D.; Wurzbacher, S.J.; Washko, S.E.; Wind, L.; Rice, A.M.; Coble, A.E.; Lajtha, K. Long-term Nitrogen Addition Decreases Organic Matter Decomposition and Increases Forest Soil Carbon. Soil Sci. Soc. Am. J. 2019, 83, S82-S95. [CrossRef]

40. Bailey, R.W.; Connor, H.E. Structural polysaccharides in leaf blades and sheaths in the Arundinoid grass Chionochloa. N. Z. J. Bot. 1972, 10, 533-544. [CrossRef]

41. Thumanu, K.; Wongchalee, D.; Mathukorn, S.; Piyaporn, P.; Toah Le, T.; Namanusert, W.; Vechklang, K.; Kaewnum, S.; Buensanteai, N. Synchrotron-based FTIR microspectroscopy of chili resistance induced by Bacillus subtilis strain D604 against anthracnose disease. J. Plant Interact. 2017, 12, 255-263. [CrossRef]

42. Wetzel, D.J.; LeVine, S.M. Biological applications of infrared microspectroscopy. In Infrared and Reman Spectroscopy of Biological Materials; Gremlich, H.U., Yan, B., Eds.; Marcel Dekker: New York, NY, USA, 2000; pp. 101-142; ISBN 978-3-5273-1993-0.

43. Kenneth, M.D.; Lawrence, C.D. Use of infrared microspectroscopy in plant growth and development. Appl. Spectrosc. Rev. 2005, 40, 301-326. [CrossRef]

44. Nelson, W.H. Modern Techniques for Rapid Microbiological Analysis, 1st ed.; Wiley-VCH: New York, NY, USA, 1991; ISBN 978-0-4711-8777-6.

45. McCann, M.C.; Hammouri, M.; Wilson, R.; Belton, P.; Roberts, K. Fourier transform infrared microspectroscopy is a new way to look at plant cell walls. J. Plant Physiol. 1992, 100, 1940-1947. [CrossRef]

46. Dokken, K.M.; Davis, L.C. Infrared imaging of sunflower and maize root anatomy. J. Agric. Food Chem. 2007, 55, 10517-10530. [CrossRef] 
47. Demyan, M.S.; Rasche, F.; Schulz, E.; Breulmann, M.; Müller, T.; Cadisch, G. Use of specific peaks obtained by diffuse reflectance Fourier transform mid-infrared spectroscopy to study the composition of organic matter in a Haplic Chernozem. Eur. J. Soil Sci. 2012, 63, 189-199. [CrossRef]

48. Campbell, M.M.; Sederoff, R.R. Variation in lignin content and composition mechanisms of control and implications for the genetic improvement of plants. J. Plant Physiol. 1996, 110, 3-13. [CrossRef]

49. Wang, J.; Zhuac, J.; Huangac, R.Z.; Yang, Y. Investigation of cell wall composition related to stem lodging resistance in wheat (Triticum aestivum L.) by FTIR spectroscopy. Plant Signal. Behav. 2012, 7, 856-863. [CrossRef]

50. Drinkwater, L.E.; Wagoner, P.; Sarrantonio, M. Legume-based cropping systems have reduced carbon and nitrogen losses. Nature 1998, 396, 262-265. [CrossRef]

51. Hammel, K.E. Fungal degradation of lignin. In Driven by Nature: Plant Litter Quality and Decomposition; Cadisch, G., Giller, K.E., Eds.; CAB International: Wallingford, UK, 1997; pp. 33-46.

52. Margenot, A.J.; Calderón, F.J.; Bowles, T.M.; Parikh, S.J.; Jackson, L.E. Soil organic matter functional group composition in relation to organic carbon, nitrogen, and phosphorus fractions in organically managed tomato fields. Soil Sci. Soc. Am. J. 2015, 79, 772-782. [CrossRef]

53. Talbot, J.M.; Yelle, D.J.; Nowick, J.; Treseder, K.K. Litter decay rates are determined by lignin chemistry. Biogeochemistry 2012, 108, 279-295. [CrossRef]

54. Talbot, J.M.; Treseder, K.K. Interactions among lignin, cellulose, and nitrogen drive litter chemistry-decay relationships. Ecology 2012, 93, 345-354. [CrossRef] [PubMed]

Publisher's Note: MDPI stays neutral with regard to jurisdictional claims in published maps and institutional affiliations.

(C) 2020 by the authors. Licensee MDPI, Basel, Switzerland. This article is an open access article distributed under the terms and conditions of the Creative Commons Attribution (CC BY) license (http://creativecommons.org/licenses/by/4.0/). 